\title{
Peningkatan Kemampuan Membaca Dengan Papan Flanel Huruf Pada Anak Kelompok B TK Asih Sejati Depok Sleman Yogyakarta
}

\author{
Suratmi \\ suratmi_mulyono@yahoo.com \\ TK Asih Sejati D.I. Yogyakarta
}

\begin{abstract}
Abstrak
Penelitian ini bertujuan untuk mendeskripsikan penggunaan flanel huruf untuk meningkatkan keterampilan membaca pada anak kelompok B TK Asih Sejati di Depok, Sleman, Yogyakarta pada 2010-2011. Subjek penelitian ini berjumlah 25 anak. Penelitian ini merupakan penelitian tindakan kelas. Metode pengumpulan data dilakukan dengan observasi. Instrumen penilaian memiliki validitas isi untuk mengukur tujuan sesuai dengan indikator dasar keterampilan peningkatan kemampuan baca TK (PKBTK) dan untuk menentukan tingkat keandalan penelitian yang dilakukan oleh dua pengamat, yaitu peneliti dengan guru lain. Hasil penelitian menunjukkan bahwa dengan menggunakan papan flanel huruf dapat meningkatkan kemampuan membaca dibandingkan dengan menggunakan media lainnya. Sebelum tindakan nilai rata-rata mencapai $36 \%$, dan setelah tindakan mencapai $64 \%$.
\end{abstract}

Kata kunci: papan flanel huruf, keterampilan membaca

\begin{abstract}
This study aims to describe the use of letters Flanel board to improve reading skills in students kindergarten group B Asih Sejati in Depok, Sleman, Yogyakarta in 2010-2011. The subjects in this study were kindergarten children Asih Sejati Group B, amounting to 25 people. This research is an action using a model of the implementation of this action research cycle by 2 cycle. Exercising for signaling conformance action by the organized action plan monitoring. Monitoring the implementation of participatory techniques, observation and use of assessment results in order to determine the degree of success in achieving the action with the form of assignment evaluation conductcd using normative criteria. An instrument as valid and does not, then the instrument has the capacity construction monitoring as outlined on the involvement of children in teaching and learning. Assessment instrument has content validity for measuring purposes in accordance with the basic skills PKBTK indicator and to determine the level of reliability with the research conducted by two observers, namely equivalence between researchers with other teachers. These results indicate that by using letters Flanel boards can improve reading skills compared to using other media. It is evident that prior to this action the average value of $36 \%$, after reaching a value of $64 \%$ action. Flanel boards use can affect the child's reading ability in group B in kindergarten Asih Sejati Depok.
\end{abstract}

Keywords: letters flanel boards, reading skill

\section{Latar Belakang}

Akhir-akhir ini tuntutan terhadap pendidikan Taman Kanak-kanak (TK) cukup banyak, baik oleh jenjang Sekolah Dasar (SD), maupun orang tua. Banyak SD menuntut bahwa anak yang masuk SD sudah harus dapat membaca, menulis dan menghitung, akibatnya pendidik TK harus memenuhi tuntutan itu agar dapat laku, demikian juga dari orang tưa banyak yang menuntut anaknya sudah dapat membaca, menulis, berhitung setelah keluar (lulus) dari TK. 
Dengan adanya tuntutan itu maka peneliti merenungkan dan merefleksi tuntutan terhadap pendidikan Taman Kanak-kanak kemudian kami melihat kurikulum Taman Kanak-kanak dan tujuan Taman Kanak-kanak.

Secara umum tujuan pendidikan

Taman Kanak-kanak adalah membantu meletakkan dasar kearah perkembangan sikap, perilaku, pengetahuan, ketrampilan dan daya cipta yang diperlukan oleh anak didik dalam menyesuaikan diri dengan lingkungannya dan untuk pertumbuhan dan perkembangan selanjutnya semua itu disesuaikan dengan tingkat penalaran anak dan umur anak (Kepmendikbud 0486/V/1992, Bab II pasal 3 ayat (1)).

Dalam RUU sisdiknas 2002 diungkapkan tujuan pendidikan Taman Kanak-Kanak untuk mengembangkan kepribadian dan potensi diri sesuai dengan tahap pertumbuhan dan perkembangan anak.

Seiring dengan perkembangan dunia pendidikan, maka dikeluarkan beberapa kebijakan baru oleh pemerintah mengenai pendidikan seperti UndangUndang Republik Indonesia No.20 tahun 2003 tentang sistem pendidikan nasional yang didalamnya ada bagian dan pasal yang menjelaskan tentang pendidikan anak usia dini, termasuk didalamnya tentang Taman Kanak-kanak (TK) yang mempunyai tujuan memfasilitasi pertumbuhan dan perkembangan anak sedini mungkin yang meliputi aspek fisik, psikis dan sosial secara menyeluruh.

Dengan demikian, sebagai guru/pendidik di tuntut untuk meningkatkan kualitas pendidikan harus dilaksanakan secara terpadu, sistematik bertahap dan berkesinambungan. Disamping itu kemampuan profesional guru dalam mengelola kegiatan belajar mengajar juga dituntut untuk dapat mempengaruhi keberhasilan anak didik dalam mencapai perkembangan optimal pribadinya. Karena itu seorang guru harus mengerti, memahami, dan menghayati berbagai prinsip pendidikan dan pengajaran serta tahap-tahap perkembangan anak sehingga guru dapat melaksanakan kegiatan belajar mengajar sesuai dengan kebutuhan tumbuh kembang anak.

Dalam proses belajar mengajar, peneliti menemukan banyak anak yang mengalami kesulitan dalam belajar membaca awal seperti, menggabungkan huruf-huruf sehingga membentuk suatu kata. Untuk itu peneliti melakukan refleksi dan perenungan untuk mencari metode atau cara agar anak mudah dalam belajar membaca awal di taman kanak-kanak dengan menggunakan potongan-potongan huruf yang dipasangkan di papanfFlanel.

Untuk mencapai tujuan dimaksud dan dalam rangka peningkatan kemampuan profesional guru, maka berbagai usaha akan ditempuh oleh guru. Guru dapat mempersiapkan pembelajaran berikutnya dengan melaksanakan perbaikan dalam kinerja melalui penelitian perbaikan pembelajaran dengan mengubah metode pembelajaran yang lama dan teknik pelaksanaan yang lebih mempermudah anak dalam belajar membaca awal di taman kanak-kanak, salah satunya dengan menggunakan papan flanel huruf bergambar.

\section{Rumusan Masalah}

Dari latar belakang masalah yang dikemukakan di atas, beberapa permasalahan yang diajukan dalam penelitian ini adalah: 1) Apakah melalui media papan Flanel huruf dapat meningkatkan kemampuan membaca awal pada anak kelompok B TK Asih Sejati Depok, Sleman Yogyakarta?, dan 2) Bagaimanakah cara meningkatkan kemampuan membaca dengan menggunakan papan Flanel huruf pada anak kelompok B TK Asih Sejati Depok, Sleman, Yogyakarta?.

\section{Tujuan Penelitian}


Tujuan yang ingin dicapai melalui penelitian ini adalah: 1) meningkatkan pemahaman tentang macam-macam huruf dan bunyinya, 2) meningkatkan pemahaman tentang huruf-huruf bila disambung menjadi kata, 3) meningkatkan daya ingat anak tentang kata dan gambar sehingga anak dapat membaca, 4) mengaktifkan anak dengan memberi kesempatan berlatih membaca dengan memasangkan huruf-huruf, 5) memperbaiki kegiatan belajar mengajar dengan sasaran akhir memperbaiki hasil belajar anak. (Raka Joni, Kardiawarman, dan Hadisubroto, 1998).

\section{Manfaat Pẹnelitian}

Hasil penelitian diharapkan dapat bermanfaat: 1) hasil penelitian ini dapat meningkatkan kemampuan membaca pada anak yang mengalami hambatan, 2) hasil penelitian ini dapat dijadikan bahan pustaka yang akan memperkaya khasanah keilmuan tentang upaya peningkatan kemampuan membaca, 3) hasil penelitian ini dapat mengembangkan kemampuan profesional guru dalam menilai dan memperbaiki pembelajaran yang dikelolanya, 4) hasil penelitian ini dapat memberikan kesempatan bagi guru untuk berperan aktif dalam mengembangkan pengetahuan serta ketrampilannya dengan menerapkan hasil temuannya, 5) hasil penelitian ini dapat meningkatkan kualitas pendidikan bagi anak, dan 6) hasil penelitian ini dapat meningkatkan mutu pendidikan sekolah sebagai lembaga penyelenggaraan pendidikan.

\section{Membaca}

Membaca adalah kegiatan berbahasa yang secara aktif menyerap informasi atau pesan yang disampaikan melalui media tulis seperti buku, artikel, modul, surat kabar, atau media tulis lainnya (Yuni Pratiwi, dkk, 2007).

Menurut para ahli, anak-anak telah memiliki alat pemeroleh bahasa dan keupayaan membaca sejak ia dilahirkan, membaca pada hakikatnya adalah kegiatan fisik dan mental untuk menemukan makna dari tulisan. Disebut kegiatan fisik karena ada bagian tubuh yaitu yang melakukannya, disebut dari kegiatan mental, karena ada bagian pikiran terutama dan ingatan terlibat didalamnya (Hartati, 1999).

\section{Membaca Dini}

Membaca dini adalah membaca yang diajarkan secara terprogram kepada anak pra sekolah program ini dititik beratkan pada perkaaan-perkataan utuh, bermakna dalam konteks pribadi anakanak dan bahan diajarkan melalui permainan dan kegiatan yang menarik sebagai perantara pembelajaran (Steinberg, 1982).

Dodge (2002) menjabarkan indikator rangkaian pengembangan bahasa bagi anak pra sekolah sebagai berikut.

- Menyimak dan berbicara

- Membaca dan menulis

Menurut Maria Montessori, anak masih berada dalam ruang lingkup anak usia dini juga dikatakan masa peka (sensitive periode), masa peka merupakan suatu masa yang ditandai dengan pesatnya perkembangan suatu fungsi jiwa yang dimiliki oleh anak seperti kemampuan membaca, menulis dan berbicara. Ketika muncul masa peka ini sangat membutuhkan adanya suatu stimulasi yang dapat mengoptimalkan perkembangannya.

\section{Media}

Menurut Gagne, media adalah berbagai jenis komponen dalam lingkungan anak yang dapat mendorong anak untuk belajar. Sedangkan Brigss berpendapat bahwa media adalah segala alat fisik yang dapat menyajikan pesan serta mendorong anak untuk belajar

\section{Media Papan Flanel}

Jenis papan kayu tipis yang dilapisi dengan kain Flanel untuk menempelkan benda yang diberi perekat. 
Meningkatkan kemampuan membaca adalah suatu aktivitas yang kompleks. Dari aktivitas-aktivitas tersebut akan menghasilkan perubahan-perubahan yang bersifat kualitatif. Kualitatif dari perubahan dipengaruhi oleh banyaknya faktor yang salah satunya adalah penggunaan alat peraga yang dapat menarik minat anak serta penerapan penguatan yang digunakan.

Apabila kita berbicara kemampuan maka kita akan menghubungkannya dengan istilah "potensi". Dalam banyak buku psikologi, potensi sering diartikan sebagai pembawaan sejak lahir atau kesanggupan untuk berkembang yang dimiliki seorang anak manusia sejak lahir. (Lubis, 1986). Ketika seorang anak manusia lahir, ia membawa segudang potensi namun potensi tersebut harus didukung oleh orang dewasa yang ada disekitarnya agar dapat berkembang secara optimal dan maksimal. Salah satu hukum perkembangan, yaitu hukum konvergensi yang dikemukakan oleh William Stern menyatakan bahwa pertumbuhan dan perkembangan yang dialami oleh seorang anak manusia dipengaruhi oleh faktor lingkungan dan pembawaan. Apabila seorang anak manusia sejak lahir diberikan stimulasi atau rangsangan pendidikan dengan baik maka akan menunjukkan hasil perkembangan yang optimal dan maksimal. Kemampuan membaca lebih banyak berkaitan dengan minat baca dan waktu pengalaman dalam membaca (Harjasujana, Mulyati, dan Titin, 1988).

Montesori menekankan pentingnya peran pendidikan dalam memberikan stimulasi berupa kesempatan dan bahan latihan agar dapat mengoptimalkan perkembangan pada masa peka tersebut.

Kegiatan membaca awal yang diajarkan terprogram kepada anak Taman Kanak-kanak harus dipersiapkan sebaikbaiknya dan bahan yang diajarkan melalui permainan dan kegiatan yang menarik. Adapun kelebihan belajar membaca dengan menggunakan papan flanel huruf adalah:

1. Anak dapat mengenal huruf dan bunyinya dengan menunjukkan potongan - potongan huruf.

2. Anak dapat menyusun huruf-huruf membentuk kata dan dipasangkan di papan flanel.

3. Anak dapat mengingat gambar dan tulisan yang di pasang di papan flanel dan ada hubungannya.

4. Anak dapat belajar membaca dengan memasangkan huruf-huruf di papan flanel sesuai dengan gambar yang dipasang.

Sebagai guru hendaknya bisa memotivasi anak untuk rajin membaca tanpa anak tersebut merasa disuruh atau dipaksa. Kegiatan belajar disesuaikan dengan perkembangan anak sehingga dapat membantu kemajuan belajar.

\section{Jenis Penelitian}

Penelitian ini merupakan penelitian tindakan kelas yang dilakukan secara kolaboratif dan partisipatif. Artinya peneliti tidak melakukan penelitian sendiri namun berkolaborasi atau bekerja sama dengan guru lain kelas A di TK Asih Sejati, Depok Yogyakarta. Secara partisipatif bersama sama melakukan dengan mitra peneliti melaksanakan penelitian ini langkah demi langkah. Penelitian ini menekankan pada kemampuan membaca dengan menggunakan papan flanel huruf.

\section{Setting Penelitian}

Kegiatan penelitian tindakan kelas ini dilaksanakan pada bulan September s/d Oktober 2010. Subjek penelitian ini adalah anak TK Asih Sejati Depok kelompok B. yang berjumlah 25 anak. Penerapan pada penelitian ini pada materi pokok kemampuan membaca.

\section{Rancangan Penelitian}

Dalam penelitian ini menggunakan model spiral dari Kemmis dan Taggart 
yang dikembangkan oleh Stephen. Kemmis dan Robin Mc Taggart yang dikutip oleh Sukardi (2004: 214) yang terdiri dari dua siklus dan masing-masing siklus menggunakan empat komponen tindakan yaitu: perencanaan, tindakan, observasi, dan refleksi dalam satu spiral yang saling terkait.

\section{Teknik Pengumpulan Data}

Teknik pengumpulan data yang digunakan adalah observasi, lembar kerja anak, format penilaian.

\section{Teknik Analisis Data}

Data yang diperoleh dari penelitian ini berupa lembar observasi dalam proses pembelajaran, lembar kerja anak dan format penilaian pada akhir siklus yang dianalisisi.

\section{Indikator Keberhasilan}

a. Meningkatkan partisipasi anak dalam pembelajaran kemampuan membaca dengan menggunakan papan flanel huruf dilihat selama proses pembelajaran berlangsung dan peningkatan persentase hasil penilaian dari $36 \%$ menjadi $64 \%$.

b. Meningkatkan rata-rata hasil belajar yang di capai anak $64 \%$.

\section{Tujuan Perbaikan Pembelajaran}

Secara umum melalui penelitian perbaikan pembelajaran ini diharapkan kualitas pembelajaran dapat meningkat. Sedangkan secara khusus, maka tujuan perbaikan pembelajaran adalah:

a. Memperbaiki kegiatan belajar mengajar dengan sasaran akhir memperbaiki hasil belajar anak (Raka, Joni, Kardia Warman dan Hadi Subroto: 1998).

b. Meningkatkan pemahaman tentang macam-macam huruf dan bunyinya.

c. Meningkatkan pemahaman tentang huruf-huruf bila disambung menjadi kata. d. Meningkatkan daya ingat anak tentang kata dan gambar, sehingga anak dapat membaca.

e. Mengaktifkan anak dengan memberi kesempatan untuk dapat berlatih membaca dengan memasangkan hurufhuruf.

\section{Hasil Penelitian}

Hasil penelitian ini
berdasarkan data yang diperoleh dari
kegiatan pembelajaran melalui upaya guru
untuk meningkatkan kemampuan
membaca dengan menggunakan papan
Flanel huruf.

Pada penelitian pembelajaran ini, peneliti bertindak sebagai guru sekaligus pengamat, peneliti menggunakan guru lain sebagai pengamat dan juga mendiskusikan hasil pengamatannya untuk perbaikan pembelajaran dan memberi masukan untuk perbaikan pembelajaran berikutnya.

\section{Siklus I}

1. Perencanaan

Dalam proses belajar mengajar, peneliti menemukan banyak anak yang mengalami kesulitan dalam belajar membaca. Penelitian pembelajaran ini dilakukan oleh peneliti dikelompo B dengan jumlah anak 25 orang. Terdiri dari 14 putra, 11 putri. Anak TK Asih Sejati Depok, Sleman. Kelompok B masih kurang minat belajar membaca, sehingga untuk meningkatkan kemampuan membaca peneliti menggunakan papan Flanel huruf.

2. Pelaksanaan tindakan

a. Melakukan proses kegiatan belajar mengajar sesuai dengan rencana pembelajaran, dengan langkahlangkah:

- Guru memperlihatkan alat peraga

- Guru menjelaskan alat peraga

- Guru menunjukkan LILA dan memberikan penjelasan tentang LILA 
- Guru memberikan tugas pada anak

- Guru memoivasi anak

- Guru memberikan reward pada anak

b. Pengorganisasian anak, posisi duduk anak menghadap ke guru

c. Posisi guru di depan anak, sehingga anak dapat melihat dengan kelas apa yang didemonstrasikan guru.

\section{Observasi}

Menganalisa dan menginterpresasikan data yang telah di peroleh selama 5 hari pada kegiatan siklus I berlangsung, dari data yang diamati kurang bagus, dari jumlah 25 anak, hanya 3 anak yang dapat nilai bagus, 9 anak mendapat niai cukup dan 13 anak mendapat nilai kurang.

Tabel Hasil Observasi Siklus I

\begin{tabular}{|c|l|c|c|c|c|c|c|}
\hline \multirow{2}{*}{ Hari ke } & \multirow{2}{*}{ Hari / tanggal } & \multicolumn{3}{|c|}{ Nilai } & \multicolumn{3}{|c|}{ Persentase } \\
\cline { 3 - 7 } & & $\bullet$ & $\sqrt{ }$ & 0 & $\bullet$ & $\checkmark$ & 0 \\
\hline 1 & Kamis 23 September 2010 & 3 & 7 & 15 & $12 \%$ & $28 \%$ & $60 \%$ \\
\hline 2 & Jum'at 24 September 2010 & 3 & 8 & 14 & $12 \%$ & $32 \%$ & $56 \%$ \\
\hline 3 & Sabtu 25 September 2010 & 3 & 9 & 13 & $12 \%$ & $36 \%$ & $52 \%$ \\
\hline 4 & Senin 27 September 2010 & 3 & 9 & 13 & $12 \%$ & $36 \%$ & $52 \%$ \\
\hline 5 & Selasa 28 September 2010 & 3 & 9 & 13 & $12 \%$ & $36 \%$ & $52 \%$ \\
\hline
\end{tabular}

\section{Tabel Siklus I}

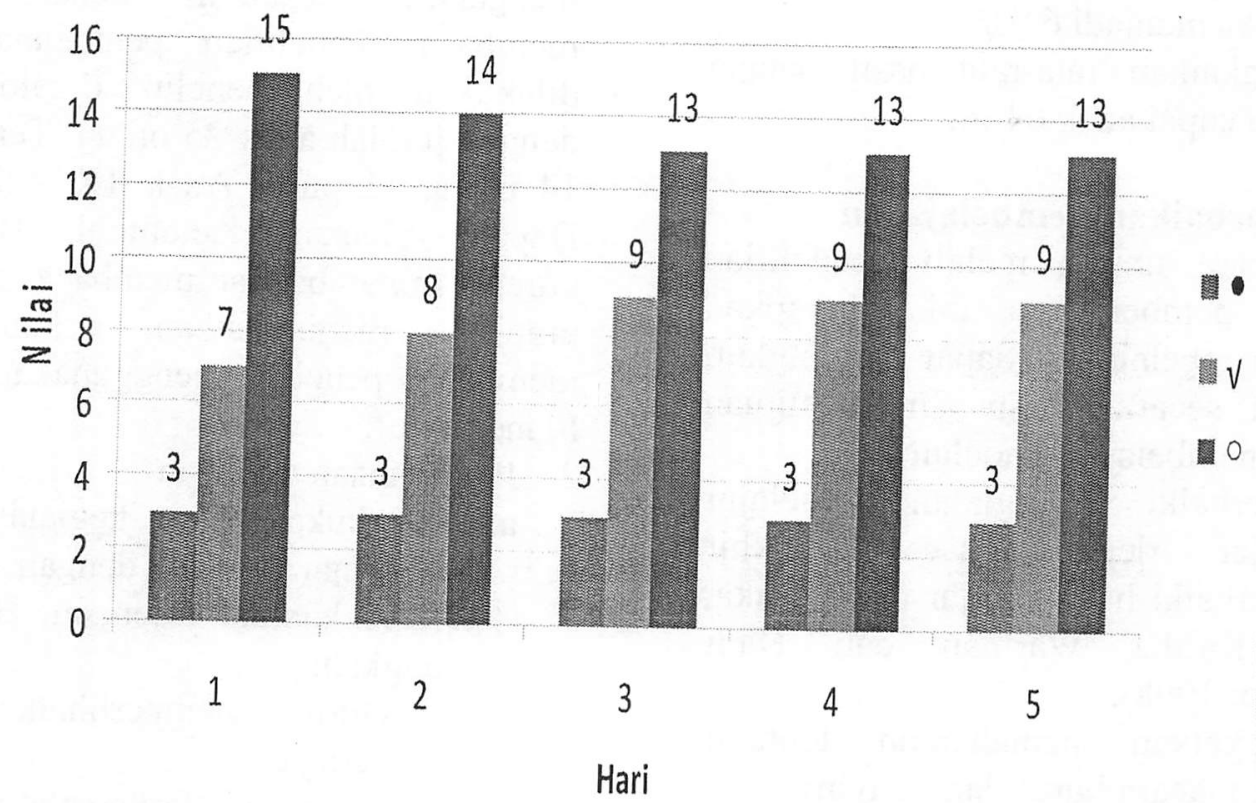


Hasil Pengamatan untuk Anak

\begin{tabular}{|c|l|c|}
\hline Hari ke & \multicolumn{1}{|c|}{ Hari / tanggal } & Skor \\
\hline 1 & Kamis 23 September 2010 & 2,16 \\
\hline 2 & Jum'at 24 September 2010 & 2,33 \\
\hline 3 & Sabtu 25 September 2010 & 2,33 \\
\hline 4 & Senin 27 September 2010 & 2,33 \\
\hline 5 & Selasa 28 September 2010 & 2,33 \\
\hline
\end{tabular}

Hasil Pengamatan Guru

\begin{tabular}{|c|l|c|}
\hline Hari ke & \multicolumn{1}{|c|}{ Hari / tanggal } & Skor \\
\hline 1 & Kamis 23 September 2010 & 2,38 \\
\hline 2 & Jum'at 24 September 2010 & 2,43 \\
\hline 3 & Sabtu 25 September 2010 & 2,43 \\
\hline 4 & Senin 27 September 2010 & 2,43 \\
\hline 5 & Selasa 28 September 2010 & 2,43 \\
\hline
\end{tabular}

4. Refleksi

Dari hasil tersebut peneliti menganalisa bahwa dalam kegiaan belajar mengajar yang di lakukan belum berhasil, ketidak berhasilan ini mungkin karena:

- Alokasi Waktu yang masih kurang

- Posisi anak kurang mendukung

- Metode mengajar dan tehnik pelaksanaan perlu diubah

- Penataan ruang yang belum maksimal

- Alat peraga yang kurang menarik

\section{Untuk itu diperbaiki pada siklus II}

1. Perencanaan

a. Memperbaiki RPP

b. Memperbaiki pelaksanaan pembelajaran

2. Pelaksanaan tindakan

a. Melakukan proses kegiatan belajar mengajar sesuai dengan
RPP yang sudah diperbaiki dengan langkah-langkah:

- Guru memperlihatkan alat peraga papan flanel huruf.

- Guru menjelaskan tugas yang akan diberikan.

- Guru memberikan tugas pada anak.

- Guru memotivasi anak.

- Guru memberikan reward pada anak.

3. Observasi

Menganalisa dan menginterprestasikan data yang telah diperoleh selama 5 hari pada kegiatan siklus II berlangsung dari data yang diamati hasilnya menjadi baik. Dari jumlah 25 anak 7 anak mendapatkan nilai bagus, 16 anak mendapatkan nilai cukup, dan 2 anak mendapatkan nilai kurang. 
Tabel Hasil Observasi (Siklus II)

\begin{tabular}{|c|l|c|c|c|c|c|c|}
\hline \multirow{2}{*}{ Hari ke } & \multirow{2}{*}{ Hari / tanggal } & \multicolumn{3}{|c|}{ Nilai } & \multicolumn{3}{c|}{ Persentase } \\
\cline { 3 - 8 } & & $\bullet$ & $\sqrt{ }$ & 0 & $\bullet$ & $\sqrt{ }$ & 0 \\
\hline 1 & Senin 18-10-2009 & 6 & 16 & 3 & $24 \%$ & $64 \%$ & $12 \%$ \\
\hline 2 & Selasa 19-10-2009 & 6 & 16 & 3 & $24 \%$ & $64 \%$ & $12 \%$ \\
\hline 3 & Rabu 20-10-2009 & 7 & 15 & 3 & $28 \%$ & $60 \%$ & $12 \%$ \\
\hline 4 & Kamis 21-10-2009 & 7 & 16 & 2 & $28 \%$ & $64 \%$ & $8 \%$ \\
\hline 5 & Sabtu 22-10-2009 & 7 & 16 & 2 & $28 \%$ & $64 \%$ & $8 \%$ \\
\hline
\end{tabular}

Tabel Siklus II

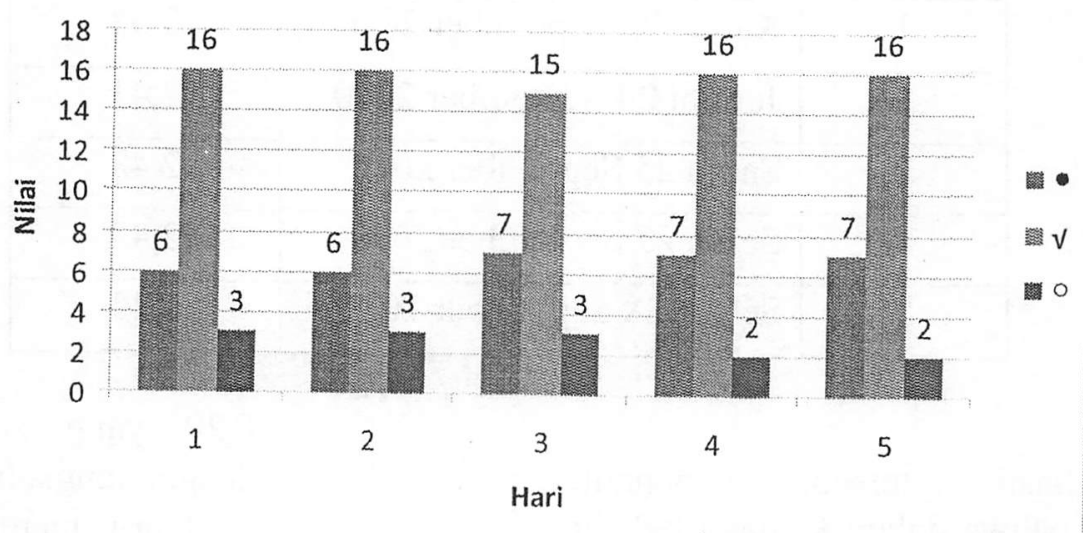

Hasil Pengamatan untuk Anak

\begin{tabular}{|c|l|c|}
\hline Hari ke & \multicolumn{1}{|c|}{ Hari / tanggal } & Skor Rata-rata \\
\hline 1 & Senin $18-10-2010$ & 2,5 \\
\hline 2 & Selasa $19-10-2010$ & 2,83 \\
\hline 3 & Rabu $20-10-2010$ & 2,83 \\
\hline 4 & Kamis $21-10-2010$ & 2,83 \\
\hline 5 & Jum'at $22-10-2010$ & 2,83 \\
\hline
\end{tabular}

Hasil Pengamatan Guru

\begin{tabular}{|c|l|c|}
\hline Hari ke & \multicolumn{1}{|c|}{ Hari / tanggal } & Skor Rata-rata \\
\hline 1 & Senin $18-10-2010$ & 2,75 \\
\hline 2 & Selasa $19-10-2010$ & 2,97 \\
\hline 3 & Rabu $20-10-2010$ & 3,16 \\
\hline 4 & Kamis $21-10-2010$ & 3,16 \\
\hline 5 & Jum'at $22-10-2010$ & 3,16 \\
\hline
\end{tabular}


4. Refleksi

Dari hasil penelitian pada siklus II, peneliti menganalisa bahwa dalam hal ini, kegiatan belajar mengajar yang dilakukan sudah berhasil.

Keberhasilan ini mungkin karena.

- Alokasi waktu sudah mencukupi

- Posisi anak sudah mendukung

- RPP sudah lebih jelas

- Pelaksanaan pembelajaran metode dan tehnik lebih tepat

- Penataan ruang dilengkapi dengan gambar yang bertulisan, di sediakan papan flanel dan huruf-huruf.

- Alat peraga sudah menarik.

\section{Pembahasan Hasil Penelitian}

Penggunaan media papan flanel huruf ternyata dapat membantu guru untuk meningkatkan kemampuan membaca pada anak TK. Menurut Gagne, media adalah berbagai jenis komponen dalam lingkungan anak yang dapat mendorong anak untuk belajar. Kekuatan dalam kegiatan ini yaitu menggunakan alat peraga langsung dan pelaksanaannya sambil bermain, maka:

1. Anak sangat antusias melihat peraga langsung.

2. Guru lebih mudah dalam menyampaikan materi pada anak.

3. Anak lebih mudah dapat menerima materi.

4. Proses belajar mengajar menjadi efektif dan efisien.

Dengan melihat adanya perubahan nilai, keberhasilan dari siklus I ke Siklus II, maka penggunaan papan flanel huruf dapa meningkatkan kemampuan anak dalam membaca, sehingga anak dapat melakukan kegiatan ini untuk dapat di refleksikan dalam kegiatan sehari-hari.

Berdasarkan pada data siklus I dan Siklus II, untuk data nilai pada siklus I ke Siklus II naik, nilai $\bullet$ dari $12 \%$ menjadi $28 \%$, nilai $\sqrt{ }$ dari $36 \%$ menjadi $64 \%$, nilai $\mathrm{O}$ dari $52 \%$ berkurang menjadi $12 \%$. Berdasarkan data tersebut, terjadi peningkatan nilai rata-rata dari $36 \%$ menjadi $64 \%$, sudah mencapai nilai ketuntasan yang diharapkan, maka penelitian ini kami anggap berhasil dan telah sesuai dengan indikator yang telah ditentukan.

\section{Kesimpulan dan Saran Kesimpulan}

Setelah penelitian perbaikan tindakan selesai dilaksanakan maka dapat diambil kesimpulan sebagai berikut:

1. Pemahaman tentang huruf atau kata dapat diungkapkan dengan baik melalui bahasa lisan atau tulisan

2. Dengan menggunakan papan flanel huruf dapat meningkatkan partisipasi belajar anak dan anak meningkatkan minat membaca.

3. Dengan menggunakan papan flanel huruf dapat meningkatkan prestasi atau kemarnpuan anak dalam belajar membaca. Hal ini dapat dilihat dari kemampuan anak didik yang meningkat lebih baik dibandingkan dengan sebelum diadakan penelitian tindakan.

\section{Saran}

Berdasarkan kesimpulan dan penelitian perbaikan tindakan peneliti mengajak untuk:

a. Mengatasi pemahaman tentang huruf atau kata, dan membaca dengan menggunakan papan flanel huruf

b. Menggunakan papan flanel huruf dapat menarik minat baca anak dan semangat anak didik untuk belajar membaca yang dapat meningkatkan kemampuan anak dalam membaca.

c. Meningkatkan keterlibatan anak didik dalam kegiatan belajar mengajar supaya anak aktif dalam pembelajaran dan tidak merasa dipaksa karena dapat sambil bermain dengan menggunakan papan flanel huruf.

d. Banyak hal yang belum sempat penulis teliti, maka penulis mengharapkan rekan-rekan untuk melanjutkan penelitian yang lebih baik lebih detail untuk meningkatkan mutu pendidikan anak didik. 


\section{Daftar Rujukan}

Departemen Pendidikan Dan Kebudayaan (1996). Metodik Khusus Pengembangan

Kemampuan Berbahasa Di Taman Kanak-Kanak, Jakarta.

Departemen Pendidikan Nasional (2002). Metode Pengembangan Kemampuan Berbahasa, Direktorat Jenderal Pendidikan Dasar Dan Menengah, Pusat Pengembangan Penataran Guru Tertulis, Bandung.

Paul Supamo (2002) Suatu Catatan Terhadap Pendidikan Taman Kanak-Kanak, Seminar Sehari Mengkritisi Potret Pendidikan Taman Kanak-Kanak Di Indonesia, Yogyakarta.

Departemen Pendidikan Nasional (2005), Pedoman Pembelajaran Di Taman Kanak-Kanak. Direktorat Jenderal Pendidikan Dasar Dan Menengah. Jakarta.
Departemen Pendidikan Nasional (2006). Standarisasi Alat Peraga / Bermain Di Taman KanakKanak, Direktorat Jenderal Manajemen Pendidikan Dasar Dan Menengah, Direktorat Pembinaan Teman Kanak-Kanak.

Siti Aisyah dkk (2007). Perkembangan dan Konsep Dasar Pengembangan Anak Usia Dini, Penerbit Universitas Terbuka.

Winda Gunarti, Lilis Suryani, Azizah Muis (2008) Metode Pengembangan Perilaku Dan Kemampuan Dasar Anak Usia Dini, Penerbit. Universitas Terbuka. 